\title{
Management and Administration Issues in Greek Secondary Schools: Self-Evaluation of the Head Teacher Role
}

\author{
Argyrios Argyriou $^{1}$ and George Iordanidis ${ }^{2}$ \\ ${ }^{1}$ General Department of Education, School of Pedagogical and Technological Education, 14121 Irakleio Attikis, Greece \\ ${ }^{2}$ Department of Primary Education, Faculty of Pedagogy, University of Western Macedonia, 3rd km of National Road Florinas-Nikis, \\ 53100 Florina, Greece \\ Correspondence should be addressed to George Iordanidis; giordanidis@uowm.gr
}

Received 20 May 2014; Accepted 11 December 2014; Published 31 December 2014

Academic Editor: Bernhard Schmidt-Hertha

Copyright (C) 2014 A. Argyriou and G. Iordanidis. This is an open access article distributed under the Creative Commons Attribution License, which permits unrestricted use, distribution, and reproduction in any medium, provided the original work is properly cited.

\begin{abstract}
This study investigated the importance school headmasters attach to a number of activities associated with the effective performance of their duties. This recording aims to examine the potential of these school headmasters to exercise their role and work within the highly bureaucratic and hierarchical Greek educational system. These activities include (a) establishment and realization of a common vision and mission of the school unit as well as its culture identification and formation, (b) teaching and tutoring of students, (c) management and development of the educational personnel, (d) conducting of administrative affairs and management of resources, and (e) good relations with parents, entities of external environment of the school unit, and the local community. The study found that the headmasters consider activities concerning their bureaucratic/conductive role as well as their leading behaviour as "very important" at very high percentages (over 70.0\%). However, tasks involving them in administrative issues are, according to them, "less" up to "least important" so that their role is effectively fulfilled. Statistically significant diversifications have been observed in certain activities associated with the efficient performance of their duties in relation to their gender, years of experience in leadership position, and the size of the school unit.
\end{abstract}

\section{Introduction}

A keen interest in the implementation of organizational and management science in education has been shown in Greece for about twenty years, following the trend that had existed in other Western countries (European Union countries, USA, Australia, and Canada). In these countries from the middle 80 s, there is not only an emphasis on educational management in both theoretical and practical level, but also a trend of decentralization of education systems with a continuing active role of the school unit in the educational process $[1,2]$.

Within this context it was expected to emerge an interest in issues concerning education such as planning, organization, aiming, learning, teaching, effectiveness, and accountability of school units and the significance of the role of school headmasters in the school administration $[2,3]$. Today, more than ever, schools are facing the need to work efficiently and improve their educational work. An efficient headmaster allows the school to manage its critical human resources more effectively [4]. In this context the role of school administration is considered to be rather significant since the educational outcome is strongly influenced by the specific organizational characteristics of each school, such as school leadership, school climate, the degree of school autonomy, and the organizational development plan, which, as a whole, arrange and define the process of school management [5-7]. Several studies, though, have showed that the appropriate school climate, leadership behaviour model, participatory governance, empowerment of school stakeholders, and other relevant parameters can be improved through the functions and practices of administration, in the process of creating an effective school [8-13].

Some other findings support that the school headmaster can indirectly promote teachers' work if the school culture is sufficiently development oriented-in other words, when careful decision making, teacher commitment, cooperation, professional development, and innovation are valued in the organization [14]. Moreover it is indicated that the school 
headmasters have a strong influence on development orientation in schools, since the performance orientation enhances the effectiveness [15]. The findings research underline that an effective goal- and innovation-oriented school headmaster can promote a development-oriented culture and improve the professionalism of the teaching staff [14].

The review of international bibliography makes clear that researches highlight the role and the mission of headmasters as one of indisputable importance for every school unit. Research on effective schools has highlighted that the headmaster of the school unit, who is asked to function as a bearer of changes, innovations, and visions, surpassing the bureaucratic dimension of his role, is one of the most important factors of their success [16-18]. However, researches show that in the centralized educational systems (similar to the Greek educational system), the headmaster of the school unit has a low degree of autonomy in his work. It constitutes, therefore, a challenge if headmasters in centralized educational systems, after acquiring the basic organizational and administrative skills through training programs and self-evaluating their work, they may accept skeptically the central educational policy and shape along with all members of the school unit, its “internal" policy, and meeting students' needs for teaching, learning, and education, as well as the various demands arising from the sociocultural environment of their area [19-21]. Consequently, the self-evaluation of the school work by the headmasters themselves is of special importance, as it is linked directly to the internal educational policy, to the development of improvement plans, and to the consolidation of a qualitative culture, within the school unit.

The specific research aims at imprinting and highlighting the way some headmasters of school units realize their role in the Greek educational system, in the frame of processing their daily tasks. It also attempts to detect in what degree their role changes, according to gender, years of service in education and in managerial post, size of the school, and the type of their training. This research paper is organized in four sections. The first is referred to as the modern educational management of the school unit, with the school's headmaster as a leader and the roles he/she is asked to undertake in every thematic area of his work. The second and the third sections describe our study and the method of data analysis along with the obtained results. Section four concludes the research paper.

\section{Theoretical Background}

Educational management is a field of study and practice concerning the operation of educational organizations as well as the administrative, financial, and bureaucratic responsibilities of school leaders. The role of the headmaster is pluralistic combining its institutional characteristics with the personality of the individual [22]. Effective headmasters' roles, as suggested by Bruggencate et al. [14], may be performed in several ways concerning behaviors in regard to rational goals, internal process, human relations, and open systems. In this survey the headmasters' responsibilities are classified into five thematic units concerning the vision and culture-orientation of school, teaching and tutoring of students, management and development of educational personnel, bureaucratic dimension of the role of the school leaders as well as their interactions with the parents, the local and wider community, or any other external stakeholders of school.

In the first thematic unit it is indicated that school management is important for defining, transferring, and achieving school objectives $[23,24]$. Effective headmasters foster a development-oriented school culture through his personality, attitude, and behaviour since the performance orientation enhances the effectiveness. They seek to create an "academic institution" by promoting high expectations and standards for students and teachers [25]. School is a dynamic interaction of many variables upon which students' chances of success depend $[14,26]$. In an excellent school, the quality in both learning and administrative proceedings makes it special and unique [27].

The second thematic unit describes the headmaster's supportive role for the entire development of students which is essential for their academic performance since "a better community member will be a better student" [28]. The role of an effective headmaster in managing student population requires good knowledge on both theory and techniques concerning human behaviour [29]. A headmaster should ensure positive school atmosphere and good teachers' work through communication and collaboration with the student population and so ensure higher academic performance and fewer dropouts [14]. The headmaster is a key factor contributing to the effectiveness of school by showing fair and true concern and respect towards students' personal strengths and weaknesses as well as enhancing group activities that promote collaboration and help students develop their sociability [30, 31].

The third thematic unit intends to present the headmaster's ability to motivate the teaching staff providing them with all necessary knowledge and skills that contribute to the effective performance of their duties [32-34]. School effectiveness and efficiency are enhanced by collaboration between the headmaster and the teaching staff as well as good communication between teachers and students [35]. An effective headmaster is required to encourage school members' teamwork and decision making and thus create constructive knowledge and a learning community in which each member develops [36, 37]. The findings of the research have shown that school leaders can promote teachers' work and important learning outcomes when careful decision-making process, teacher commitment, cooperation, professional development, and innovation are positively valued in the organization $[14,38]$.

The fourth thematic unit deals with the obligation of school headmasters to apply all necessary bureaucratic procedures in order to handle administrative issues. Therefore, a headmaster should be aware of the current legislation, the structure and functions of the Greek educational system, the organizing and updating of the school record, the application of practices that ensure security, cleanness, hygiene, and aesthetics conditions of the school environment, and the pursuit and management of funds and equipment [33]. His/her knowledge, skills, and experience are essential in dealing with administrative issues successfully, especially in small 
schools where secretarial activities are partly carried out by the teaching staff as extracurricular work unless secretarial support operates with the help of an administrative employee, as provided by the Greek educational system. An effective headmaster is also required to make effective use of the time available while planning all necessary activities [39]. It is also important that he/she is efficient with the use of new technologies and information systems [40] while encouraging the administrative and teaching staff of the school to use these educational tools.

The fifth thematic unit focuses on the headmaster's responsibility to build trusting relationships with parents [41, 42], various external entities [43], and the wider community [44]. This resonates with Epstein's theory of overlapping spheres [45] asserting that "students learn more and succeed at higher levels when home, school, and community work together to support students' learning and development" [46]. Effective schools ensure effective communication with parents [47]. Therefore headmasters should implement an "open door" policy based on a participatory approach and encourage periodical meetings with the parents-guardians so that they cope with issues concerning school performance, objectives, or difficulties as well as students' behaviour and progress. An effective headmaster should also develop relationships with other schools at a local, national, or European level, exchange practices, and establish school networks so as to implement common action plans [37]. In addition, he/she should raise awareness of the performance of school and encourage interactive positive attitude towards the cultural wealth of social, national, racial, religious, and so forth, groups that make up the local community so that school becomes a domain of cooperation with particular reference to students development and socialization.

In the current survey, in five thematic areas which include forty suggestions, we tried to investigate in what way headmasters of school units evaluate their role and their work, aiming that our survey results will be useful in planning suitable training programs which will help headmasters to organize and administrate their schools more effectively, while applying internal educational policy. Since this policy is anthropocentric, it is linked directly to the self-evaluation of headmasters' work, as it leads both to the development of creative educational managers and to the development of teachers who really care about their job, eliminate their isolation, and get actively involved in the various processes that take place in their schools [48]. Concurrently, through selfevaluation of their work, headmasters get the opportunity to improve the administration of their human resources, which, under the appropriate motivation, it is possible that it will play a crucial role in the upgrading of the educational results. The study of "National Criteria for Headmasters" showed that the self-evaluation of headmasters' work, aiming at their continuous and constant personal development, is an important parameter of their role [49].

\section{Research Methodology}

The aim of the current survey is to examine the importance of a series of activities according to the opinion of schools' headmasters while performing their duties. The necessity of research in this specific scientific field is motivated by the following reasons.

(1) Though the research process, it is demonstrated that the role of the headmaster is crucial for launching changes in schools and for the achievement of positive results [50-52]. This implies that the data highlighted by this survey can contribute to headmasters' understanding the personal or more general weaknesses, aiming at improvement.

(2) All researches-having the contribution of the headmasters in the improvement of the school unit, as a scientific objective-give high priority to the training of educational managers. This training, provided that it will be implemented based on scientific methods, will highlight the headmasters' aspect about their needs, fully preparing them for their task and setting self-evaluation as a primary element of the school unit evolution.

In particular, the current survey focuses on the following questions.

(i) Which significance is attributed by the headmasters to a series of activities related with the overall guidance and administration of their school units?

(ii) Which significance is attributed by the headmasters to a range of activities related with the learning and the education of their students?

(iii) Which significance is attributed by the headmasters to a range of activities related to the management and development of their educative personnel?

(iv) Which significance is attributed by the headmasters to a range of activities related with the settling of administrative matters and the management of the available funds and resources in the school unit?

(v) Which significance is attributed by the headmasters to a series of activities regarding the relations with parents, external authorities, and the local community?

(vi) Do the headmasters' views regarding other factors like sex, age, and years of previous experience in education differentiate according to management position, the type of school they manage as well as the number of school classes, and the various types of training?

In order to collect data, a questionnaire was distributed to all the Western Attica Secondary Education headmasters by using a purposive sample. The survey was of the "review" type. In order to check the clarity of the questions, a pilot survey was carried out, in which 11 headmasters participated. The questionnaire took its final form taking into account the results of this pilot study. The data of the survey was provided by the 109 questionnaires that were answered out of the 154 questionnaires that were delivered. $108(70.6 \%)$ of the participant headmasters were men and 46 (29.4\%) were women. Their average age was 52 years old. 75 of them $(49.0 \%)$ had 22 to 28 years of previous experience. 85 (54.9\%) ran high 
schools, while $138(90.2 \%)$ manage schools with more than 8 classes. Lastly, $87(56.6 \%)$ had less than 8 years managerial experience.

The research tool of this research has been used by Koutouzis et al. [53] in a similar survey, conducted by the Educational Research Centre (ERC) in Greece during implementation of subproject 1: "addressing the operation of the administrative education services" of the project "Assessment of the way services and institutionalized education operate" under the O. P. "Education" II (Operational Programme for Education and Initial Vocational Training II), Third Community Support Framework's, funded programmes.

The main questioning theme and the specific issues of this research led to the selection of the dependent and independent variables. The questions concerning a series of activities related with the headmasters' work correspond to dependent variables. The aim of the current survey is to examine the importance that headmasters attribute to these activities while performing their duties. In particular, the participants were asked to express their views on seven questions regarding activities related with the overall guidance and direction of their school units, choosing one from the 4-level Likert scale (1. very important, 2. important, 3. less important, and 4 . the least important), in order to avoid the central tendency error, that is, the tendency of the subjects to opt for answers around the middle of the scale. The reliability of the seven questions was checked using the internal coefficient of reliability "alpha" of Cronbach. The check proved that the coefficient is reliable $\alpha=.64$.

In the following stage, the participants were asked to answer nine, five, and fourteen questions, respectively, regarding activities related to the learning and the education of their students, the management and development of the educative personnel and the carrying out of administrative matters, and the management of the available funds as well as resources in the school unit, using the Likert scale for their answers. The reliability of the selected questions was tested using the internal coefficient of reliability (alpha of Cronbach) and all of them proved to be very reliable: as far as the nine questions are concerned $\alpha=.78$, as to the five questions $\alpha=.72$ and the fourteen questions $\alpha=.74$. Additional dependent variables (five questions) covered the activities which the headmasters performed in their relations with parents, other external entities, and the local community. Answers were graded based on the Likert scale. These five questions performed a high internal coefficient of reliability (alpha of Cronbach) $\alpha=.74$.

In the next step the significance attributed by the headmasters to a series of activities while performing their duties regarding each thematic unit was correlated to independent variables. Sex, years of experience in teaching and in managing schools, and the type of school they ran were used as independent variables.

\section{Research Results}

According to the type of the research and its objectives, statistical analysis was divided into two levels: univariate and bivariate analysis. The statistical program SPSS17.0 was used in order to process the data. In the following subsections are presented the results obtained by the univariate and bivariate analysis.

(i) Univariate analysis: the mean (M), the standard deviation (s), and the percent of the answers given by the survey participants, for each activity/variable, are depicted, using the 4-level Likert scale. Note: $1=$ very important activity, $2=$ important activity, $3=$ less important activity, and $4=$ the least important activity. At means in bold a statistically significant difference was observed $(P=.05)$.

(ii) Bivariate analysis: control of statistically significance of the differences in the means of the dependent and the independent variables, with the aid of the Pearson chi-square, Mann-Whitney $U$, and KruskalWallis $H$ nonparametric tests. The use of these three nonparametric tests was put into practice after the control of the normality of the dependent variables in accordance with the normality test of KolmogorovSmirnov as well as Monte Carlo simulation technique. For the inspection of normality, both Asymp. Sig. (2tailed) and Monte Carlo Sig. were taken into account for all the dependent variables. Since $P$ value for all the dependent variables is less than .05, the hypothesis of data normality is therefore rejected.

\section{Vision and Culture-Orientation of School}

The activities "directly resolving problems that arise (functional or interpersonal)," "leading in the formation and establishment of a common vision for the school unit," and "defining as well as configuring school culture" are considered "very important" by the largest percentage of participant headmasters. The other four activities of the first unit are considered by the headmasters "important" up to "very important."

A statistical significance is found in relation to the sex of the headmaster regarding the activity-variable "running conferences of the school committee" $(Z=-2.54, P=.01)$. The female headmasters (Mean Rank = 18.72) stated that the above activity is much more important than for their male colleagues (Mean Rank = 29.33). Descriptive statistics for this analysis are presented in Table 1.

\section{Teaching and Tutoring of Students}

The activities "contributing in the observation and implementation of the timetable" and "contributing in the observation and implementation of the curriculum" are considered "very important," while they consider the other seven activities of the second unit "important" up to "very important." Moreover, the activities "issuing results for students' graduation" and "forming classes" are considered "less important" down to "least important" by $20.0 \%$ and $33.4 \%$ of the participant headmasters, respectively.

A statistical significance is found in relation to the various types of training of headmasters regarding the activityvariable "issuing results for students' graduation" $(Z=-1.95$, $P=.01)$. The headmasters who have a Master's degree 
TABLE 1: The significance of activities related to the overall guidance and administration of the school unit.

\begin{tabular}{|c|c|c|c|c|c|c|c|}
\hline & Activities/variables & $\mathrm{M}$ & $s$ & $1 \%$ & $2 \%$ & $3 \%$ & $4 \%$ \\
\hline 1 & $\begin{array}{l}\text { Directly resolving problems that arise (functional or } \\
\text { interpersonal) }\end{array}$ & 1.12 & 0.325 & 88.2 & 11.8 & 0.0 & 0.0 \\
\hline 2 & Defining as well as configuring school culture & 1.53 & 0.620 & 73.2 & 20.4 & 6.4 & 0.0 \\
\hline 3 & $\begin{array}{l}\text { Leading in the formation and establishment of a } \\
\text { common vision for the school unit }\end{array}$ & 1.58 & 0.613 & 67.9 & 25.8 & 6.3 & 0.0 \\
\hline 4 & $\begin{array}{l}\text { Cooperating with people involved and authorities in } \\
\text { order to address problems }\end{array}$ & 1.49 & 0.543 & 46.9 & 45.1 & 5.0 & 2.0 \\
\hline 5 & Establishing rules/regulations for students & 1.74 & 0.820 & 44.7 & 40.4 & 10.6 & 4.3 \\
\hline 6 & Establishing rules/regulations for the personnel & 1.87 & 0.797 & 42.0 & 40.9 & 12.8 & 4.3 \\
\hline 7 & Running conferences of the school committee & 1.84 & 0.834 & 39.2 & 41.2 & 15.7 & 3.9 \\
\hline
\end{tabular}

TABLE 2: The significance of activities related to the learning and the education of the students.

\begin{tabular}{|c|c|c|c|c|c|c|c|}
\hline & Activities/variables & M & $\mathrm{s}$ & $1 \%$ & $2 \%$ & $3 \%$ & $4 \%$ \\
\hline 1 & $\begin{array}{l}\text { Contributing in the observation and implementation of } \\
\text { the timetable }\end{array}$ & 1.43 & 0.575 & 70.8 & 25.3 & 3.9 & 0.0 \\
\hline 2 & $\begin{array}{l}\text { Contributing in the observation and implementation of } \\
\text { the curriculum }\end{array}$ & 1.49 & 0.543 & 64.9 & 21.1 & 2.0 & 0.0 \\
\hline 3 & $\begin{array}{l}\text { Promoting innovative initiatives (i.e., European } \\
\text { programs, holding seminars for students concerning } \\
\text { health education, drug use, etc.) }\end{array}$ & 1.59 & 0.536 & 47.1 & 50.9 & 2.0 & 0.0 \\
\hline 4 & Taking actions to confront special groups of students & 1.66 & 0.717 & 46.0 & 44.0 & 8.0 & 2.0 \\
\hline 5 & $\begin{array}{l}\text { Communicating and keeping up to date with students' } \\
\text { boards }\end{array}$ & 1.67 & 0.683 & 45.1 & 43.1 & 11.8 & 0.0 \\
\hline 6 & Managing and monitoring the examinations procedure & 1.67 & 0.766 & 44.0 & 42.2 & 11.8 & 2.0 \\
\hline 7 & $\begin{array}{l}\text { Organizing students' field trips in areas of cultural } \\
\text { interest and their participation in other activities }\end{array}$ & 1.75 & 0.659 & 43.2 & 45.0 & 11.8 & 0.0 \\
\hline 8 & Issuing results for students' graduation & 1.82 & 0.800 & 40.0 & 40.0 & 18.0 & 2.0 \\
\hline 9 & Forming classes & 2.19 & 0.842 & 30.8 & 35.8 & 27.1 & 6.3 \\
\hline
\end{tabular}

consider the above activity to be "very important" (Mean Rank =16.21). Also, statistical significance is found in relation to headmasters that have six-month training regarding the activities-variables "issuing results for students' graduation" $(Z=-1.97, P=.01)$ and "organizing students' field trips in areas of cultural interest and their participation in other activities" $(Z=-2.12, P=.01)$. The headmasters who have six-month training consider the above activities "very important" (Mean Rank $=10.50$ \& 10.01, resp.). Descriptive statistics for this analysis are presented in Table 2.

\section{Management and the Development of Educational Personnel}

The activities "communicating and keeping up to date with the teacher association" and "welcoming newly employed teachers and newcomers effectively" are considered "very important" by the largest percentage of participant headmasters. They also consider the activities "evaluating teachers' work" and "facilitating teachers' professional development" "important." It is remarkable to notice that the activities "evaluating teachers' work" and "facilitating teachers' professional development" appear to be of minor importance for a considerable percentage of survey participants $(29.6 \%$ and $31.9 \%$ for the above activities, resp.).

A statistical significance is found in relation to the various types of training of headmasters regarding the activitiesvariables "observing teachers' work" $(Z=-2.11, P=.01)$ and "welcoming newly employed teachers and newcomers effectively" ( $\mathrm{Z}=-1.25, P=.01)$. The headmasters who have six-month training consider the above activities very important (Mean Rank $=9.50$ \& 11.00, resp.). Descriptive statistics for this analysis are presented in Table 3.

\section{Bureaucratic Dimension of the Role of the School Headmaster}

The following activities "ensuring educational staff of all specialties from the beginning of the school year and throughout the school year," "ensuring all necessary teaching means from the beginning of the school year and throughout the school year (i.e., textbooks and computers)," "complying fully with the current educational legislation and on equal terms for the entire educational staff," "taking actions so that the school acquires and maintains its technological equipment," and "knowing educational legislation and keeping abreast of 
TABLE 3: The significance of activities related to the management and development of their educative personnel.

\begin{tabular}{|c|c|c|c|c|c|c|c|}
\hline & Activities/variables & M & s & $1 \%$ & $2 \%$ & $3 \%$ & $4 \%$ \\
\hline 1 & Communicating and keeping up to date with the teacher association & 1.3 & 0.463 & 80.0 & 20.0 & 0.0 & 0.0 \\
\hline 2 & Welcoming newly employed teachers and newcomers effectively & 1.43 & 0.502 & 76.8 & 23.2 & 0.0 & 0.0 \\
\hline 3 & Observing teachers' work & 1.82 & 0.755 & 70.8 & 12.9 & 14.3 & 2.0 \\
\hline 4 & Evaluating teachers' work & 2.16 & 0.888 & 57.7 & 12.7 & 20.5 & 9.1 \\
\hline 5 & Facilitating teachers' professional development & 2.17 & 0.732 & 17.0 & 51.1 & 29.8 & 2.1 \\
\hline
\end{tabular}

current educational acts" are considered "very important" by the largest percentage of participant headmasters.

The headmasters also consider the following activities "finding funds for school operation," "submitting the necessary reports to the Ministry of Education," "submitting the necessary reports to the supervising educational authorities," and "communicating and keeping up to date with the school committee" to be "important." It is remarkable to observe that the last three of the above activities are of minor importance to a considerable percentage of survey participants $(34.0 \%$, $37.3 \%$, and $28.0 \%$, resp.).

The activities "submitting documents to other services" and "filling in data requested by other services" are considered "less important" down to "least important" by the largest percentage of participant headmasters.

The activity "submitting documents to other services" consists an exception and displays statistical significance in relation to the experience in a managerial position $\left(x^{2}=8.30\right.$, $\mathrm{df}=3, P=.01)$ and the number of school classes $\left(x^{2}=6.72\right.$, $\mathrm{df}=3, P=.01)$. The participant headmasters with five up to ten and over fifteen years of experience in a managerial position consider the above activity "less important" down to "least important" (Mean Rack $=31.50$ and 28.00, resp.). Instead, the participant headmasters with eleven up to fifteen and less than five years of experience in a managerial position consider the above activity "important" up to "very important" (Mean Rack $=21.50$ and 18.05, resp.). Furthermore, the participant headmasters who manage school units with less than eight classes consider the above activity "less important" down to "least important" (Mean Rack $=39.70$ ), while those who manage school units with more than eight classes consider the above activity "important" up to "very important" (Mean Rack = 23.47).

The activity "submitting the necessary reports to the supervising educational authorities" appears to have statistical significance in relation to the type of school the headmasters manage $\left(x^{2}=9.85, \mathrm{df}=3, P=.01\right)$. The headmasters who manage General High Schools consider the above activity "less important" down to "least important" (Mean Rack = 33.12), while those who manage Junior High Schools and Technical Schools regard the above activity as "important" (Mean Rack $=24.58$ and 21.50, resp.). Moreover, those who manage Vocational High schools regard it as "very important" (Mean Rack = 13.50).

A statistical significance is found in relation to the various types of training of headmasters regarding the activitiesvariables "complying fully with the current educational legislation and on equal terms for the entire educational staff"
$(Z=-2.06, P=.01)$. The headmasters who have a Master's degree consider the above activity "very important" (Mean Rank $=17.00)$. Also, statistical significance is found in relation to headmasters that have six-month training regarding the activity-variable "keeping school records, protocol, students' registry book, etc." ( $Z=-1.97, P=.01)$. The headmasters who have six-month training also consider the above activity "very important" (Mean Rank $=10.50$ ). Descriptive statistics for this analysis are presented in Table 4.

\section{Interactions with Parents, Local Community, and Any External Stakeholders}

The survey participants consider the five activities-variables of the fifth unit mainly "important." It is remarkable to observe that the activity "connecting the school unit either with the job market and authorities or with the professional needs of the local community" is of minor importance to a considerable percentage of survey participants (30.0\%).

The activity-variable "communicating and be informed by Municipal Authorities" displays a statistical significance in relation to the various types of training (the headmasters who have either Doctorate of Philosophy $Z=-2.04, P=.04$, a Master's degree $Z=-2.21, P=.01$, or six-month training $Z=-2.53, P=.01)$. The headmasters who have either Doctorate of Philosophy, a Master's degree, or six-month training consider the above activity "very important" (Mean Rank $=7.00,15.57$, and 7.00, resp.).

The activity-variable "communicating and keeping up to date with the parents' association" displays a statistical significance regarding the survey participants who have a Master's degree $(Z=-2.02, P=.01)$. The headmasters who have a Master's degree regard the above activity as "very important" (Mean Rank = 15.93).

The activity-variable "promoting and organizing seminars in order to inform parents" displays a statistical significance regarding the headmasters who have six-month training $(Z=-2.12, P=.01)$. The headmasters who have sixmonth training consider the above activity "very important" (Mean Rank $=6.50$ ). Descriptive statistics for this analysis are presented in Table 5.

\section{Conclusions and Discussion}

In this study, the outcomes arising from the processing of the questionnaires reflect the way headmasters perceive their role in the efficient handling of their daily tasks. Indeed, our main 
TABLE 4: The significance of activities related to the carrying out of administrative matters and the management of the available funds and resources in the school unit.

\begin{tabular}{|c|c|c|c|c|c|c|c|}
\hline & Activities/variables & M & s & $1 \%$ & $2 \%$ & $3 \%$ & $4 \%$ \\
\hline 1 & $\begin{array}{l}\text { Ensuring educational staff of all specialties from the } \\
\text { beginning of the school year and throughout the school } \\
\text { year }\end{array}$ & 1.13 & 0.334 & 87.5 & 12.5 & 0.0 & 0.0 \\
\hline 2 & $\begin{array}{l}\text { Ensuring all necessary teaching means from the } \\
\text { beginning of the school year and throughout the school } \\
\text { year (i.e., textbooks and computers) }\end{array}$ & 1.18 & 0.385 & 82.4 & 17.6 & 0.0 & 0.0 \\
\hline 3 & $\begin{array}{l}\text { Taking actions so that the school acquires and } \\
\text { maintains its technological equipment }\end{array}$ & 1.46 & 0.542 & 76.0 & 22.0 & 2.0 & 0.0 \\
\hline 4 & $\begin{array}{l}\text { Complying fully with the current educational legislation } \\
\text { and on equal terms for the entire educational staff }\end{array}$ & 1.39 & 0.568 & 74.7 & 21.4 & 3.9 & 0.0 \\
\hline 5 & $\begin{array}{l}\text { Knowing educational legislation and keeping abreast of } \\
\text { current educational acts }\end{array}$ & 1.39 & 0.532 & 72.7 & 25.3 & 2.0 & 0.0 \\
\hline 6 & $\begin{array}{l}\text { Taking actions in order to resolve operational matters } \\
\text { (building maintenance, etc.) }\end{array}$ & 1.56 & 0.577 & 48.0 & 48.0 & 4.0 & 0.0 \\
\hline 7 & Managing current funds & 1.63 & 0.631 & 45.1 & 47.1 & 7.8 & 0.0 \\
\hline 8 & $\begin{array}{l}\text { Keeping school records, protocol, students' registry } \\
\text { book, and so forth }\end{array}$ & 1.82 & 0.800 & 40.0 & 40.0 & 18.0 & 2.0 \\
\hline 9 & Finding funds for school operation & 1.71 & 0.610 & 22.3 & 69.9 & 7.8 & 0.0 \\
\hline 10 & $\begin{array}{l}\text { Submitting the necessary reports to the supervising } \\
\text { educational authorities }\end{array}$ & 2.20 & 0.775 & 19.6 & 43.1 & 35.3 & 2.0 \\
\hline 11 & $\begin{array}{l}\text { Submitting the necessary reports to the Ministry of } \\
\text { Education }\end{array}$ & 2.30 & 0.839 & 14.0 & 52.0 & 24.0 & 10.0 \\
\hline 12 & $\begin{array}{l}\text { Communicating and keeping up to date with the school } \\
\text { committee }\end{array}$ & 2.04 & 0.781 & 10.0 & 62.0 & 24.0 & 4.0 \\
\hline 13 & Filling in data requested by other services & 2.60 & 0.818 & 6.2 & 35.7 & 37.5 & 20.6 \\
\hline 14 & Submitting documents to other services & 2.63 & 0.883 & 6.1 & 38.9 & 29.6 & 25.4 \\
\hline
\end{tabular}

TABLE 5: The significance of activities regarding the relations of their school units with parents, external authorities, and the local community.

\begin{tabular}{|c|c|c|c|c|c|c|c|}
\hline & Activities/variables & M & $\mathrm{s}$ & $1 \%$ & $2 \%$ & $3 \%$ & $4 \%$ \\
\hline 1 & $\begin{array}{l}\text { Communicating and be informed by Municipal } \\
\text { Authorities }\end{array}$ & 1.94 & 0.676 & 15.5 & 64.9 & 19.6 & 0.0 \\
\hline 2 & $\begin{array}{l}\text { Communicating and keeping up to date with the } \\
\text { parents' association }\end{array}$ & 1.96 & 0.807 & 15.0 & 63.0 & 18.0 & 4.0 \\
\hline 3 & $\begin{array}{l}\text { Promoting and organizing seminars in order to inform } \\
\text { parents }\end{array}$ & 1.92 & 0.640 & 14.5 & 69.2 & 16.3 & 0.0 \\
\hline 4 & $\begin{array}{l}\text { Taking actions to put my school and its problems as } \\
\text { well as its activities in the local community on display } \\
\text { (mass media, creating a webpage, etc.) }\end{array}$ & 1.88 & 0.683 & 14.4 & 67.9 & 17.7 & 0.0 \\
\hline 5 & $\begin{array}{l}\text { Connecting the school unit either with the job market } \\
\text { and authorities or with the professional needs of the } \\
\text { local community }\end{array}$ & 2.16 & 0.866 & 12.0 & 58.0 & 22.0 & 8.0 \\
\hline
\end{tabular}

research tool was designed to include a series of activities administrated by school headmasters. These activities correspond to the five thematic units analyzed in the theoretical part of our work and are connected with the main responsibilities of headmasters for the effective implementation of their duties. In this context, the survey results highlight the potential of school leaders to exercise administrative and pedagogical work with a view to improving the effectiveness of their schools, within the highly bureaucratic and hierarchical Greek education system.
More specifically, the quantitative data of the questionnaires show that headmasters consider activities associated with their bureaucratic and conductive role as "very important," at very high percentages (over 70.0\%) ensuring the provision of all necessary teaching material, that is, books, PCs, and so forth, from the beginning and during the school year, making efforts so that schools acquire and maintain technological equipment, having knowledge of the educational legislation and keeping abreast of the currently applicable educational provisions, applying the current educational 
legislation to the teaching staff consistently and fairly, and contributing to the observance and implementation of the school timetable and analytical program. Indeed, the headmaster deals with the administrative operation of the school as an organization through bureaucratic procedures involving day-to-day routine and conductive administrative tasks [54].

At the same time, efficient headmasters consider activities associated with their administrative, pedagogical, and leading role as "very important," at very high percentages (over $70.0 \%$ ) (addressing directly the functional or interpersonal problems that may arise, communicating with teachers and the teachers' association, informing and getting informed by them, organizing effectively the welcoming of the newly employed teachers at school, identifying and formatting the culture of school, and having the key role in forming and establishing a common vision in the school unit). In these issues the effective school leader's role is crucial due to his obligation to embody specific knowledge, skills, and experience so as to be able to cope with school administration effectively [27, 31, 49, 55-58]. In a survey conducted in Great Britain by Rhodes et al. [59] more than 50.0\% of the research subjects supported the finding that the four characteristics which highlight the leadership talent are the "human capacities," the "communication skills," the "due respect to the staff," and the "development of vision." At this point it is interesting to note that the above-mentioned research data on the importance headmasters attach to activities related to their leading role are not consistent with a series of research data results about how headmasters allocate their working time $[60,61]$. It was indicated that headmasters spend most of their working time on bureaucratic/conductive activities arising from legislation implementation and administrative issues which could contribute to the improvement of the quality and effectiveness of the school unit [54, 62-64].

A very essential observation, however, is that the activity with the second higher percentage $(87.5 \%)$ related to the ensuring of a sufficient number of teachers for the effective functioning of the school unit does not fall within the headmaster's responsibilities since in the Greek educational system this activity depends on the educational administrative authorities on the level of prefecture, periphery, and mainly of the Ministry of Education. According to the "bureaucratic" leading model of Greek educational system, headmasters ought to address these administrative services for the resolution of the issues concerned. The former ascertainment expresses the headmasters' anxiety and concern about the presence and stability of the teaching staff from the beginning and during the school year. Series of studies conducted in recent decades showed that the absence, mobility, and frequent changes of the teaching staff in the beginning or during the school year create problems concerning planning as well as carrying out several activities while affecting the cohesion of the school unit and eventually students' performance [65].

As regards activities which are not considered to be important by headmasters, it can be noted that their engagement in activities concerning bureaucratic/administrative issues are, in their opinion, "less up to least important" for the effective fulfillment of their role. As a matter of fact, certain activities such as "filling in data requested by supervising services" as well as "submitting documents to other services" concerning the answer choices of "very important up to important" appear to be an aggregate of relative frequencies, namely, $47.9 \%$ and $49.0 \%$, respectively. This finding could be attributed to the fact that such activities of administrative type could be simplified and assigned to secretarial personnel who could assist headmasters with the options offered by modern technology at schools $[40,66]$. The fact that educational systems regarded as effective (e.g., Finland) have facilitated headmasters by providing them with adequate administrative and secretarial personnel [67-70] shows that relevant initiatives should be taken in Greece, too.

The fact that activities involving evaluation and testing (assessing and monitoring the work of teachers) show in total satisfactory prices of relevant frequencies in choice "very important" (57.7\% and 70.8\%, resp.) is nevertheless interesting. That means that the evaluation and monitoring are considered as "very important" activities by the Greek headmasters of school units [71]. In particular, submitting documents to other services is considered as an activity of very little importance by headmasters with professional experience in leadership function who run small schools. This finding could be attributed to the little significance ascribed by headmasters to bureaucratic/administrative type of activities which not only absorb a significant part of their daily working time but also engage them deeply in the suffocating hierarchical institutional framework that limits their potential for meaningful involvement in making and handling administrative decisions as well as for proper use of their relevant autonomy. Therefore, unlike the traditional type of school administration common features of which are the suffocating control by the central administration and the limited autonomy of the participants, Headmasters with leadership experience seek a new form of school administration characterized by enlarged autonomy, enhanced teachers' association, positive climate of mutual cooperation, and responsible participation among members of the school community [72].

A very significant observation in relation to this finding is the fact that bureaucratic activities of administrative type such as "submitting necessary reports to the Ministry of Education" and "submitting necessary reports to supervising educational authorities" give an aggregate of relevant frequencies, namely, $34.0 \%$ and $37.3 \%$, for the options "less up to the least important," respectively. Compliance with hierarchy initially seems to be right as regards headmasters' obligation to keep senior officials informed about the work and activities of the school unit so that validity of the processes and supervision of school leaders are ensured. This procedure is necessary to be carried out under the responsibility of headmasters who are required to represent school by submitting relevant reports wherever necessary and participating in meetings held by senior hierarchy. This communication aims at encountering problems arising at school while obtaining necessary information on conducting educational changes and reforms [65]. However, the headmasters' obligation to provide their superiors with exceptionally frequent information should raise questions since this time-consuming bureaucratic procedure reinforces and reproduces centralism of power of the Greek 
Educational system through constant supervision [53]. Due to the combination of the centralized administration system in accordance with the exceptionally frequent informing procedure in a hierarchically vertical bottom-up process the headmaster cannot devote considerable working time so as to develop a leading profile and deal with administrative and pedagogical activities which could essentially help improve quality and effectiveness of school, such as the management of the available resources in the school unit, the management and professional development of the school teachers and personnel, students' performance, learning outcomes and the overall education of their students, and dealing with external stakeholders and the local community $[14,15,42,46,73,74]$. This finding seems to be accepted by General High School headmasters who consider the above bureaucratic activities to be "less up to least important."

The significant statistical differentiation observed in the activity of "chairing meetings of the school committee" which is related to the headmasters' gender can be attributed to the need of female school leaders to become accepted and approved for the effective fulfillment of their role through chairing meetings of the school commission and therefore overturn the initial disbelief of both their male and female colleagues towards them [75-78]. This ascertainment could be attributed to the different leading behaviour model adopted by both sexes. Actually, female school leaders encourage participation, share their authority and information with members of the school unit, and rely on their communication skills in order to have a positive effect on others when exercising their leading role; on the contrary, male school leaders rely on their authority expressing the male stereotype of their administrative behaviour by applying a control and order system so as to affect others [33, 79-83].

Statistically significant variation is, also, noticeable in connection with headmasters who hold training or postgraduate titles of study and participate in activities related mainly to their administrative or pedagogical role such as "issuing the results for the graduation and promotion of students," "organizing visits in areas of cultural interest and participation in various activities for students," "monitoring the teachers work," "organizing effectively the welcoming of the newly employed teachers at school," "communicating and getting informed by the Local Authorities," "communicating and getting informed by the Association of Parents," "promoting the organizing of information seminars for parents," and "promoting the connection between the school and the labour market, the stakeholders, or the professional needs of the local community." This finding proves that in secondary education the more the headmasters increase the level of their additional studies, the more they feel the need to be concentrated on activities related to their ability to motivate, encourage. and activate all members of their school unit. This is supported by a series of research showing that headmasters with increased level of additional studies they encourage, support, guide and strengthen students and educational personnel, develop and evolve the school unit, take initiatives, and implement innovations [84]. All the above data are of great interest as they highlight the model of headmaster that school and society need today as opposed to the model of school leader who is confined to fulfill the operating educational issues within the bureaucratic dimension of his role (structure and functioning of the educational system, basic legislation, reports, statistical tables submitted to the supervising educational authorities, etc.) due to the centralized character of the Greek educational system. In conclusion, the leadership of the school requires leaders who not only know their staff but know themselves too [85]. This specific work can serve as a feedback tool for managers and help increase the self-awareness of their effectiveness, identifying areas where managers need improvement. It is necessary to prepare such studies, so that the makers of educational policy will have the opportunity to use their research results, in order to enhance school effectiveness.

\section{Conflict of Interests}

The authors declare that there is no conflict of interests regarding the publication of this paper.

\section{References}

[1] R. Dale and S. Robertson, "Local states of emergency: The contradictions of neo-liberal governance in education in New Zealand," British Journal of Sociology of Education, vol. 23, no. 3, pp. 463-482, 2002.

[2] Organisation for Economic Co-Operation and Development (OECD), Teachers Matter: Attracting, Developing and Retaining Effective Teachers, OECD, Paris, France, 2005.

[3] P. Pashiardis and S. Brauckmann, "Evaluation of school principals," in International Handbook on the Preparation and Development of School Leaders, G. Crow, J. Lumby, and P. Pashiardis, Eds., pp. 1-17, Routledge, London, UK, 2008.

[4] M. Tschannen-Moran, Trust Matters: Leadership for Successful Schools, Jossey-Bass, San Francisco, Calif, USA, 2004.

[5] P. Mortimore, Effective Schools: Current Impact and Future Potential, Institute of Education, London, UK, 1995.

[6] P. Sammons, "School effectiveness and equity: making connections. Embracing diversity: new challenges for school improvement in a global learning society," in Proceedings of the International Congress for School Effectiveness, Fort Lauderdale, Fla, USA, 2006.

[7] J. White, "Philosophical perspectives on school effectiveness and school improvement," The Curriculum Journal, vol. 8, no. 1, pp. 29-44, 1997.

[8] T. Bush, Theories of Educational Management, Paul Chapman, London, UK, 1995.

[9] G. Crow, J. Lumby, and P. Pashiaris, "Introduction: why an international handbook on the preparation and development of school leaders?" in International Handbook on the Preparation and Development of School Leaders, J. Lumby, G. Crow, and P. Pashiardis, Eds., pp. 1-17, Routledge, London, UK, 2008.

[10] C. Day, Developing Teachers: The Challenges of Lifelong Learning, Falmer Press, London, UK, 1999.

[11] A. Hargreaves, "Restructuring: post modernity and the prospects of educational change," Journal of Education Policy, vol. 9, no. 1, pp. 47-65, 1994.

[12] V. Petzko, "The perceptions of new principals regarding the knowledge and skills important to their initial success," NASSP Bulletin, vol. 92, no. 3, pp. 224-250, 2008. 
[13] E. Shein, Organizational Culture and Leadership, Jossey-Bass, San Francisco, Calif, USA, 1985.

[14] G. Bruggencate, H. Luyten, J. Scheerens, and P. Sleegers, "Modeling the influence of school leaders on student achievement: how can school leaders make a difference?" Educational Administration Quarterly, vol. 48, no. 4, pp. 699-732, 2012.

[15] J. Scheerens and R. Bosker, The Foundations of Educational Effectiveness, Pergamon, Oxford, UK, 1997.

[16] J. Brewer and J. Blasé, “Ten steps to success," Journal of Staff Development, vol. 22, no. 1, pp. 30-31, 2001.

[17] K. B. Everard, G. Morris, and I. Wilson, Effective School Management, Paul Chapman, London, UK, 4th edition, 2004.

[18] R. Wiliamson and B. R. Blacburn, "Personal and shared vision: a commitment to increased rigor," Principal Leadership, vol. 10, no. 3, pp. 56-59, 2009.

[19] D. Leech and C. R. Fulton, "Faculty perceptions of shared decision making and the principal's leadership behaviours in secondary schools in a large urban district," Education, vol. 128, no. 4, pp. 630-644, 2008.

[20] T. J. Sergiovanni, The Principalship: A Reflective Practice Perspective, Allyn and Bacon, Needham Heigths, Mass, USA, 1991.

[21] H. S. Williams, "Leadership capacity-a key to sustaining lasting improvement," Education, vol. 130, no. 1, pp. 30-41, 2009.

[22] A. Durbin, Basic Principles Management, N. Sarri, Ed., Ellin Publishing, Athens, Greece, 4th edition, 1998.

[23] J. Bamburg and R. Andrews, "School goals, principals and achievement," School Effectiveness and School Improvement, vol. 2, no. 3, pp. 175-191, 1990.

[24] K. Leithwood, P. Begley, and B. Cousins, "The nature, causes and consequences of principals' practices: an agenda for future research," Journal of Educational Administration, vol. 28, no. 4, pp. 5-31, 1990.

[25] P. Mortimore, "School effectiveness and the management of effective learning and teaching," School Effectiveness and School Improvement, vol. 4, pp. 290-310, 1993.

[26] D. Reynolds and C. Teddlie, "The processes of school effectiveness," in The International Handbook of School Effectiveness Research, C. Teddlie and D. Reynolds, Eds., pp. 134-159, Falmer Press, London, UK, 2000.

[27] B. Caldwell and J. Spinks, Leading the Self-Managing School, Falmer Press, London, UK, 1992.

[28] N. Noddings, "What does it mean to educate the whole child?" Educational Leadership, vol. 63, no. 1, pp. 8-13, 2005.

[29] M. Fullan, Change Forces with a Vengeance, Routledge Falmer, London, UK, 2003.

[30] G. Pashiardis, "School climate in elementary and secondary schools: views of Cypriot principals and teachers," International Journal of Educational Management, vol. 14, no. 5, pp. 224-237, 2000.

[31] A. Kythreotis, P. Pashiardis, and L. Kyriakides, "The influence of school leadership styles and culture on students' achievement in Cyprus primary schools," Journal of Educational Administration, vol. 48, no. 2, pp. 218-240, 2010.

[32] B. Becker and M. Smith, "Social contexts and processes that influence effective school principals," Journal of Cross-Disciplinary Perspectives in Education, vol. 4, no. 1, pp. 10-17, 2011.

[33] K. B. Everard and G. Morris, Effective School Management, Paul Chapman, London, UK, 3rd edition, 1996.

[34] A. Saiti and C. Saitis, "In-service training for teachers who work in full-day schools. Evidence from Greece," European Journal of Teacher Education, vol. 29, no. 4, pp. 455-470, 2006.
[35] I. Halawah, "The relationship between effective communication of high school principal and school climate," Education, vol. 126, no. 2, pp. 334-345, 2005.

[36] H. M. Marks and S. M. Printy, "Principal leadership and school performance: an integration of transformational and instructional leadership," Educational Administration Quarterly, vol. 39, no. 3, pp. 370-397, 2003.

[37] Organisation for Economic Co-Operation and Development (OECD), Improving School Leadership. Volume I: Policy and

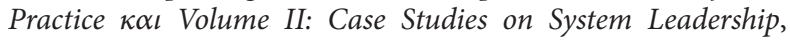
OECD, Paris, France, 2008.

[38] B. Jensen, What Teachers Want: Better Teacher Management, Grattan Institute, Melbourne, Australia, 2010.

[39] H. Tomlinson, Educational Leadership. Personal Growth for professional Development, Paul Chapman, London, UK, 2004.

[40] W. Cunningham and P. Cordeiro, Educational Leadership: A Problem-Based Approach, Pearson, Boston, Mass, USA, 2006.

[41] A. MacBeth, "Preconceptions about parents education?" in Parents and Schools: Customers, Managers, or Parents, P. Munn, Ed., Routledge, London, UK, 1993.

[42] A. Saiti, "School leadership and educational equality: analysis of Greek secondary school data," School Leadership and Management, vol. 27, no. 1, pp. 65-78, 2007.

[43] W. K. Hoy and C. G. Miskel, Educational Administration: Theory, Research and Practice, McGraw-Hill, New York, NY, USA, 2007.

[44] M. Khalifa, "A re-new-ed paradigm in successful urban school leadership: principal as community leader," Educational Administration Quarterly, vol. 48, no. 3, pp. 424-467, 2012.

[45] J. L. Epstein, "Toward a theory of family-school connections: teacher practices and parent involvement," in Social intervention: Potential and Constraints, K. Hurrelman, F. Kaufmann, and F. Losel, Eds., pp. 121-136, Aldine, New York, NY, USA, 1987.

[46] J. L. Epstein and M. G. Sanders, "Prospects for change: preparing educators for school, family, and community partnerships," Peabody Journal of Education, vol. 81, no. 2, pp. 81-120, 2006.

[47] S. Brauckmann and P. Pashiardis, "From PISA to LISA: new educational governance and school leadership: exploring the foundations of a new relationship in an international context," in Proceedings of the 90th Annual Meeting of the American Educational Research Association, San Diego, Calif, USA, 2009.

[48] J. Nias, "Why teachers need their colleagues: a developmental perspective," in International Handbook Of Educational Change Part II, A. Hargreaves, A. Lieberman, M. Fullan, and D. Hopkins, Eds., Kluwer, Dodrecht, The Netherlands, 2001.

[49] DFES, National Standards for Headmasters, DFES, Nottingham, UK, 2004.

[50] K. Lieberman, L. K. Seashore, S. Anderson, and K. Wahlstrom, How Leadership Influences Student Learning, University of Minnesota, Center for Applied Research and Educational Improvement, Minneapolis, Minn, USA, 2004.

[51] T. Waters, R. J. Marzano, and B. McNulty, Balanced Leadership: What 30 Years of Research Tell Us about the Effect of Leadership on Student Achievement, Mid-Continent Research for Education and Learning, Aurora, Colo, USA, 2003.

[52] J. West-Burnham and O. Fergus, Leadership and Professional Development in Schools: How to Promote Techniques for Effective Professional Learning, London, UK, Pearson Education, 1998.

[53] E. Koutouzis, S. Kuranakis, M. Mauraki, and P. Mpithara, Assessment of the Way Services and Institutionalized Education Operate, The Education Research Centre of Greece, Athens, Greece, 2008. 
[54] P. Pashiardis, "Secondary principals in Cyprus: the views of the principal versus the views of the teachers-a case study," International Studies in Educational Administration, vol. 29, no. 3, pp. 11-27, 2001.

[55] M. Burlingame, "Theory into practice: educational administration and the cultural perspective," in Leadership and Organizational Culture. New Perspectives in Administrative Theory and Practice, T. Sergiovanni and E. J. Corbally, Eds., University of Illinois Press, Chicago, Ill, USA, 1984.

[56] C. Glickman, S. Gordon, and J. Ross-Gordon, Supervision and Instructional Leadership: A Developmental Approach, Allyn \& Bacon, Boston, Mass, USA, 2001.

[57] D. Goleman, R. Boyatzis, and A. McKee, Primal Leadership: Learning to Lead with Emotional Intelligence, Harvard Business School Press, Boston, Mass, USA, 2002.

[58] T. Sergiovanni, "Leadership and excellence in schooling," Educational Leadership, vol. 41, no. 5, pp. 4-13, 1984.

[59] C. Rhodes, M. Brundrett, and A. Nevill, "Leadership talent identification and development: perceptions of heads, middle leaders and classroom teachers in 70 contextually different primary and secondary schools in England," Educational Management Administration and Leadership, vol. 36, no. 3, pp. 311335, 2008.

[60] P. V. Bredeson, "An analysis of the metaphorical perspectives of school principals," in School Leadership: A Contemporary Reader, J. L. Burden, Ed., pp. 297-317, Sage, Newbury Park, Calif, USA, 1989.

[61] L. Davies, "The role of the primary school head," Educational Management Administration \& Leadership, vol. 15, no. 1, pp. 4347, 1987.

[62] A. Huczynski and D. Buchanan, Organizational Behavior: An Introductory Text, Prentice Hall, London, UK, 2001.

[63] A. McEwen and M. Salters, "Values and management: the role of the primary school headteacher," School Leadership and Management, vol. 17, no. 1, pp. 69-80, 1997.

[64] Z. Rosenblatt and A. Somech, "The work behavior of Israel elementary school principals: expectations versus reality," $E d u$ cational Administration Quarterly, vol. 34, no. 4, pp. 505-532, 1998.

[65] C. Saitis, The Principal in the State School, PI Ministry of Education, Athens, Greece, 2008.

[66] Organisation for Economic Co-operation and Development (OECD), Education Policy Advice for Greece, Strong Performers and Successful Reformers in Education, OECD, Paris, France, 2011.

[67] Ministry of Education Finland, Improving School Leadership. Finland Background Report, Ministry of Education Finland, 2007.

[68] Organisation for Economic Co-Operation and Development (OECD), Education at a Glance 2009: OECD Indicators, 2009, http://www.oecd-ilibrary.org/education/education-at-a-glance2009_eag-2009-en.

[69] A. Ylonen, "The reinvention of the comprehensive school system in Finland: how do market-oriented reforms impact upon equity and equality of opportunity?” Forum, vol. 51, no. 1, pp. 9-24, 2009.

[70] A. West and A. Ylönen, "Market-oriented school reform in England and Finland: school choice, finance and governance," Educational Studies, vol. 36, no. 1, pp. 1-12, 2010.

[71] G. Iordanidis, The Role of the Head of Directorate and Office of Education, Kyriakidis Brothers, Thessaloniki, Greece, 2002.
[72] D. Muijs and A. Harris, "Teacher leadership in (In)action: three case studies of contrasting schools," Educational Management Administration and Leadership, vol. 35, no. 1, pp. 111-134, 2007.

[73] P. Hallinger and J. Murphy, "The social context of effective schools," American Journal of Education, vol. 94, no. 3, pp. 328 355, 2014.

[74] P. Pashiardis, "Researching the characteristics of effective primary school principals in cyprus: a qualitative approach," Educational Management Administration and Leadership, vol. 26, no. 2, pp. 117-130, 1998.

[75] V. Brinia, "Male educational leadership in Greek primary schools: a theoretical framework based on experiences of male school leaders," International Journal of Educational Management, vol. 25, no. 2, pp. 164-185, 2011.

[76] M. Coleman, The Experience of Women and Men Secondary Principals, UNITEC, Auckland, New Zealand, 2003.

[77] A. Addi-Raccah and H. Ayalon, "Gender inequality in leadership positions of teachers," British Journal of Sociology of Education, vol. 23, no. 2, pp. 157-177, 2002.

[78] S. Valentine and L. Godkin, "Supervisor gender, leadership style, and perceived job design," Women in Management Review, vol. 15, no. 3, pp. 117-129, 2000.

[79] L. Babcock and S. Laschever, Women Don't Ask: The High Cost of avoiding Negotiation-Andpositive Strategies for Change, Bantom Books, New York, NY, USA, 2007.

[80] A. H. Eagly and B. T. Johnson, "Gender and leadership style: a meta-analysis," Psychological Bulletin, vol. 108, no. 2, pp. 233 256, 1990.

[81] S. H. Helgesen, The Female Advantage: Women's Ways of Leadership, Currency Doubleday, New York, NY, USA, 1995.

[82] J. M. Steward, Common characteristics of women leaders in higher education administration [M.S. thesis], Department of Planning, Public Policy and Management, University of Oregon, 2009.

[83] P. Werhane, M. Posig, L. Gundry, L. Ofstein, and E. Powell, Women in Business: The Changing Face of Leadership, Praeger Publishers, Westport, Conn, USA, 2007.

[84] T. Bush and D. Glover, Leadership Development: Evidence and Beliefs, Lincoln University, Lincoln, UK, 2004.

[85] T. Sergiovanni, Value Added Leadership: How to Get Extraordinary Performance in Schools, Harcourt Brace Jovanovich, Orlando, Fla, USA, 1990. 

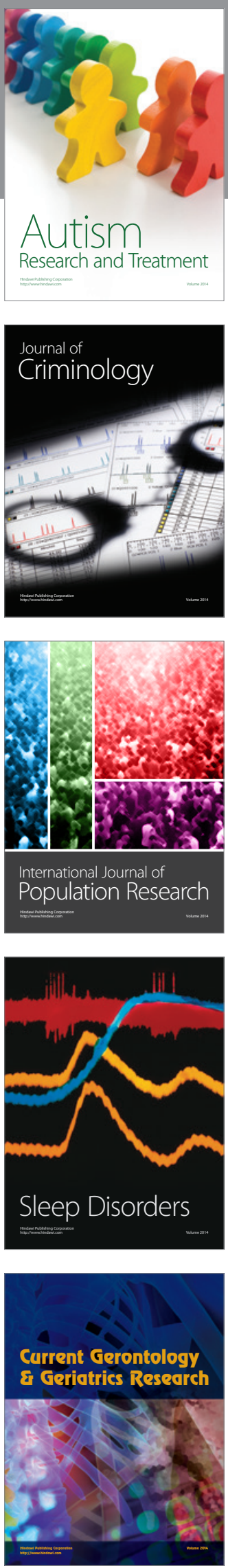
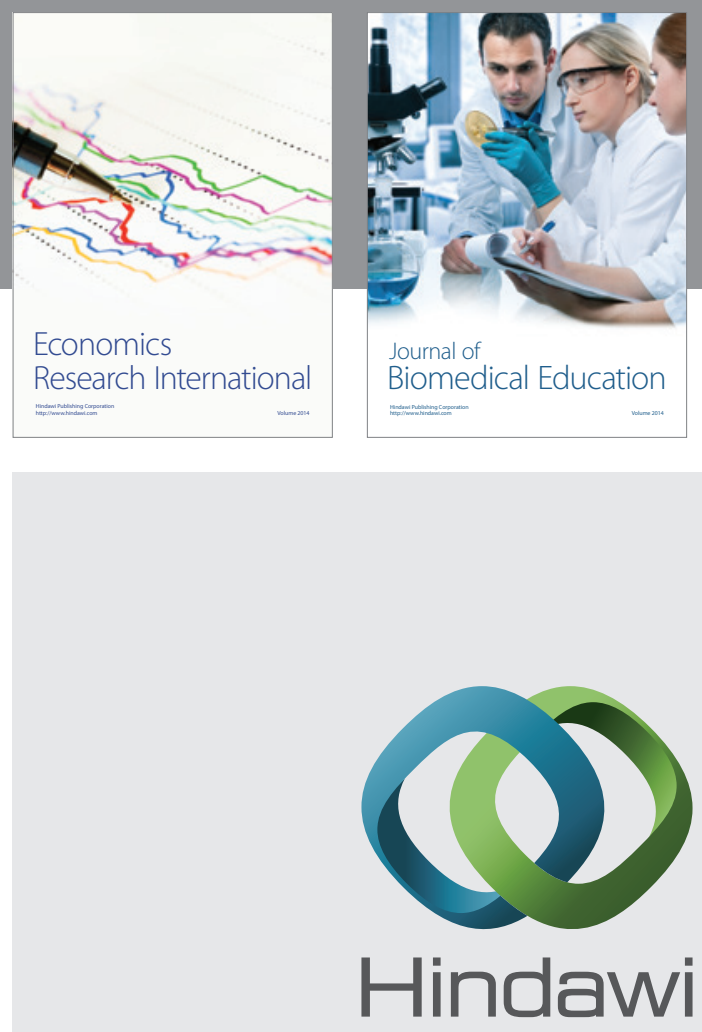

Submit your manuscripts at

http://www.hindawi.com
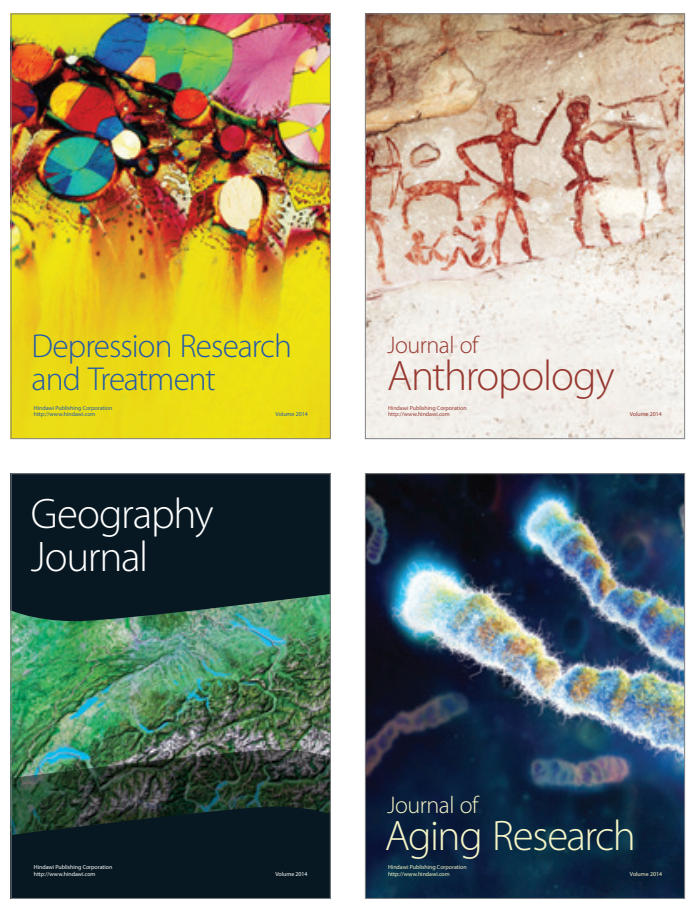
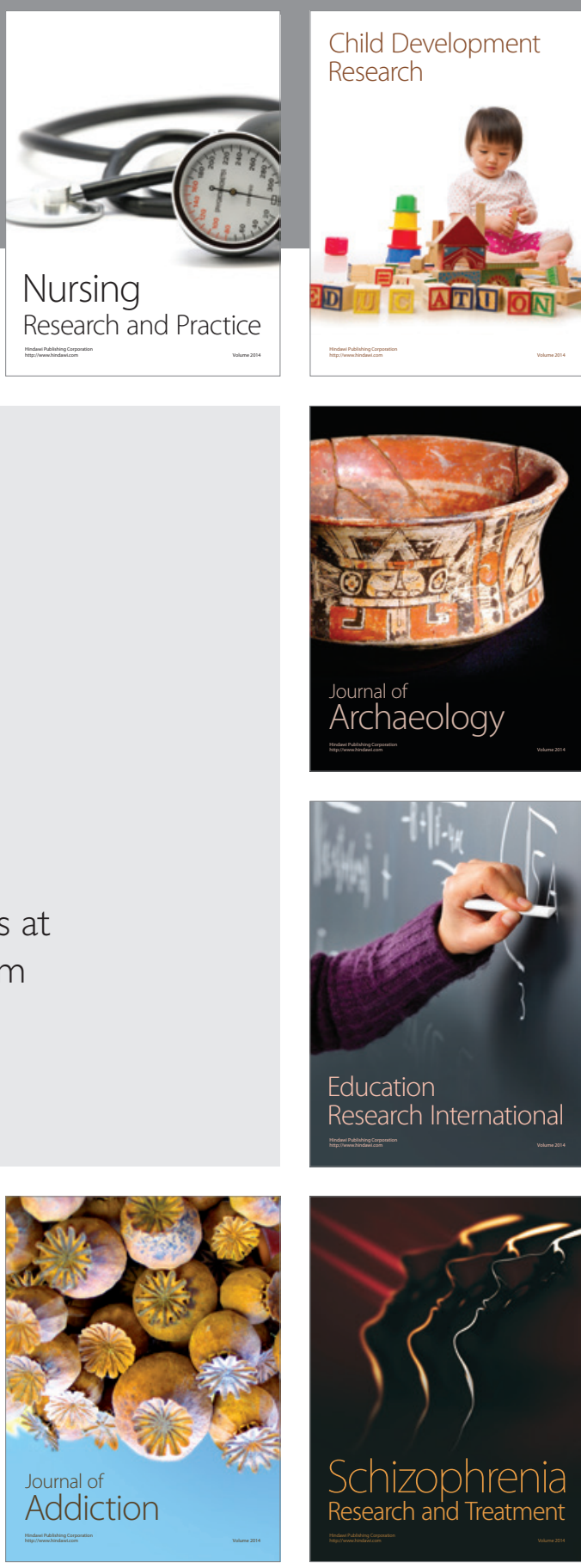

(D)
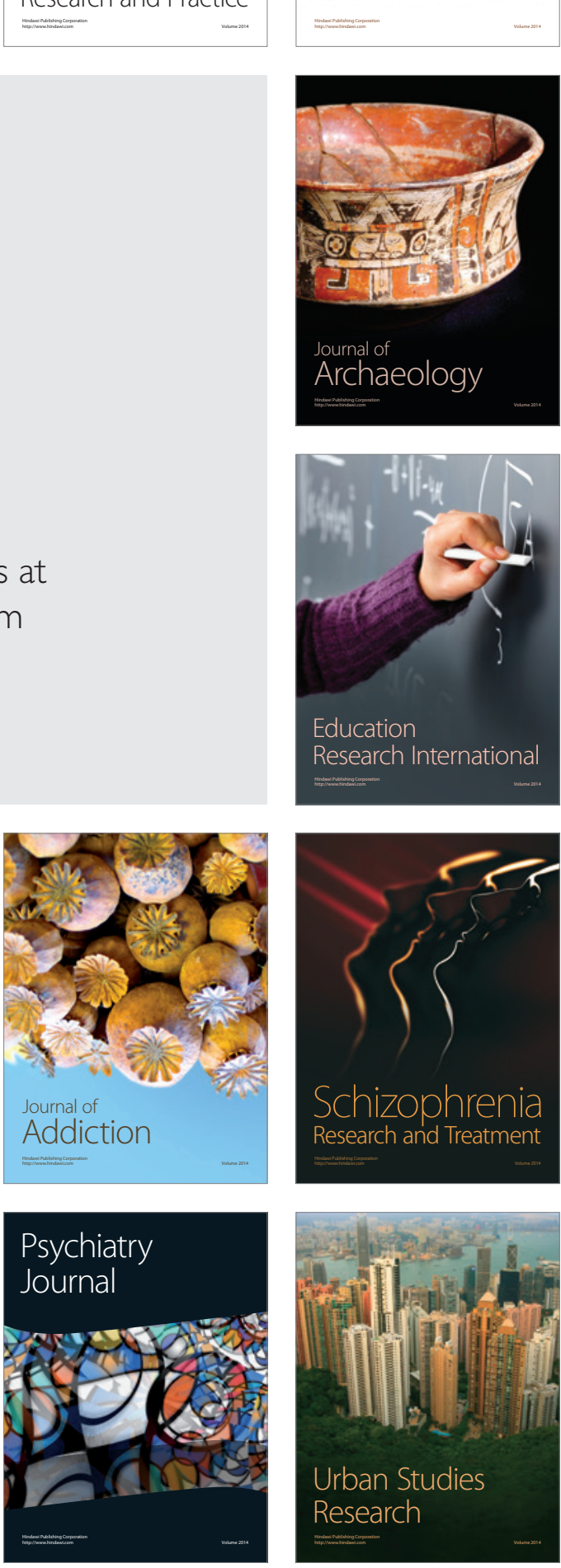